\title{
PENINGKATAN KESEJAHTERAAN PSIKOLOGIS PADA PENDERITA DIABETES MELLITUS TIPE 2 DENGAN MENGGUNAKAN GROUP POSITIVE PSYCHOTHERAPY
}

\section{IMPROVEMENT OF PSYCHOLOGICAL WELL-BEING IN PATIENTS WITH TYPE 2 DIABETES MELLITUS USING GROUP POSITIVE PSYCHOTHERAPY}

\author{
Rima Christine Sujana \\ Hepi Wahyuningsih \\ Qurotul Uyun \\ Fakultas Psikologi dan Ilmu Sosial Budaya Universitas Islam Indonesia \\ rima.sujana@yahoo.com
}

\begin{abstract}
This study aims to determine the improvement of psychological well-being in patients with type 2 diabetes mellitus using group positive psychotherapy. Subjects in this study were 12 patients with type 2 diabetes mellitus (men and women) between the ages of 47-64 years, and divided into two groups, namely the experimental group and the control group. This study uses a scale of psychological well-being (22-item), which refers to the dimensions of psychological well-being by Ryff (1989). Quantitative data analysis using parametric analysis techniques one-way repeated measures anova to see the differences in psychological well-being of the experimental group after the subject therapy. The results show that there are differences in psychological well-being in the experimental group after therapy, with a value of Wilks' Lambda $=$ $0.153, p=0.00(p<0.01)$. The conclusion from this study that the group positive psychotherapy can improve psychological well-being of people with type 2 diabetes mellitus.
\end{abstract}

Key words: Group Positive Psychotherapy, Psychological Well Being, Type 2 Diabetes Mellitus.

\begin{abstract}
ABSTRAK
Penelitian ini bertujuan untuk mengetahui peningkatan kesejahteraan psikologis pada penderita diabetes mellitus tipe 2 dengan menggunakan group positive psychotherapy. Subjek dalam penelitian ini adalah 12 penderita diabetes mellitus tipe 2 berjenis kelamin laki-laki dan perempuan dengan usia antara 47-64 tahun, dan terbagi menjadi dua kelompok, yaitu kelompok eksperimen dan kelompok kontrol. Penelitian ini menggunakan skala kesejahteraan psikologis (22 aitem) yang mengacu pada dimensi-dimensi kesejahteraan psikologis menurut Ryff (1989). Analisis data kuantitatif menggunakan teknik analisis parametrik one-way repeated measures anova untuk melihat perbedaan kesejahteraan psikologis kelompok eksperimen setelah subjek diberikan terapi. Hasilnya menunjukkan bahwa ada perbedaan kesejahteraan psikologis pada kelompok eksperimen setelah diberikan terapi, dengan nilai Wilks' Lambda $=0.153, p=$ $0.00(p<0.01)$. Kesimpulan dari penelitian ini bahwa group positive psychotherapy dapat meningkatkan kesejahteraan psikologis penderita diabetes mellitus tipe 2 .
\end{abstract}

Kata Kunci: Psikoterapi Positif Kelompok, Kesejahteraan Psikologis, Diabetes Mellitus Tipe 2 
Kesehatan merupakan hal penting dalam hidup manusia. Ketika terkena penyakit, maka seseorang mulai menyadari bahwa kesehatan mahal harganya. Berdasarkan data Dinas Kesehatan Daerah Istimewa Yogyakarta tahun 2013 diketahui bahwa pola penyakit pada semua golongan umur telah mulai didominasi oleh penyakit-penyakit degeneratif, terutama penyakit yang disebabkan oleh kecelakaan, neoplasma, kardiovaskuler dan diabetes mellitus. Laporan Survailans Terpadu Penyakit (STP) Puskesmas di Daerah Istimewa Yogyakarta pada tahun 2012 menunjukkan bahwa penyakit diabetes mellitus (7.434 kasus) masuk dalam urutan ke tiga dan ke lima dari distribusi 10 besar penyakit berbasis STP Puskesmas (DepKes, 2013).

Diabetes mellitus disebut the great imitator karena diabetes mellitus termasuk penyakit yang menyebabkan komplikasi pada bagian tubuh yang jika penanganannya tidak dilakukan dapat menyebabkan kematian (Sam, 2007). Menurut Tjokroprawiro (2006), penyakit diabetes melitus dapat menyerang semua organ tubuh berupa komplikasi penyakit, seperti kebutaan, gagal ginjal, stroke, dan jantung. Seseorang yang sudah dinyatakan memiliki diabetes mellitus harus melakukan pengobatan seumur hidup.

Diabetes mellitus merupakan pe- nyakit yang paling kompleks dan menuntut banyak perhatian maupun usaha dalam pengelolaannya dibandingkan dengan penyakit kronis lainnya, karena penyakit diabetes tidak dapat diobati namun hanya dapat dikelola (Kusumadewi, 2011). Diabetes mellitus merupakan kelompok penyakit metabolik dengan karakteristik hiperglikemia yang terjadi karena kelainan sekresi insulin, kerja insulin atau keduanya yang harus dilakukan pengelolaan sehingga tidak terjadi komplikasi lebih lanjut. Pengelolaan diabetes mellitus meliputi edukasi, terapi gizi medis, latihan jasmani dan intervensi farmakologis yang dapat diberikan melalui edukasi terpadu (Yulishati, 2014).

Hayes dan Ross (Temane \& Wissing, 2006) mengemukakan bahwa kesejahteraan psikologis dapat dipredikisi oleh kesehatan fisik yang baik. Apabila kesehatan fisik berada dalam kondisi rendah atau buruk, maka akan meningkatkan perasaan sedih, patah semangat terhadap masa depan, merasa sangat letih, serta mengalami penurunan kepercayaan diri dan disiplin diri. Diabetes mellitus tipe 2 sangat erat kaitannya dengan gaya hidup penderita sebab diabetes mellitus tipe 2 selain karena faktor keturunan, penyebab utamanya adalah gaya hidup mengenai makanan 
yang dikonsumsi dan olahraga (Buckman \& McLaughlin, 1999).

Dikemukakan oleh Karlsen (2002) bahwa penyakit diabetes mellitus khususnya tipe 2 menuntut seseorang untuk melakukan perubahan dalam gaya hidupnya terkait dengan diet dan olahraga yang harus dilakukan serta melakukan pengobatan oral secara ruti. Menurut Jacobson (Karlsen, 2002), penyakit diabetes mellitus memberikan pengaruh pada kesejahteraan psikologis seseorang karena gejala dan perawatan yang memberatkan penderita serta komplikasi yang dapat melemahkan dan bahkan dapat mengancam jiwa seseorang. Apabila tidak dilakukan kontrol yang tepat terhadap reaksi-reaksi psikologis atau respon-respon secara emosional, khususnya ketika tidak ada hal yang dapat dilakukan penderita untuk mengubah situasi, maka penderita cenderung mengalami ketidakmampuan penyesuaian secara fisik dan kesejahteraan psikologis (Sarafino, 1997).

Kesejahteraan psikologis merupakan pencapaian penuh dari potensi psikologis seseorang dan suatu keadaan ketika individu dapat menerima kekuatan dan kelemahan diri apa adanya, memiliki tujuan hidup, mengembangkan relasi yang positif dengan orang lain, menjadi pribadi yang mandiri, mampu mengen- dalikan lingkungan dan terus betumbuh secara personal (Ryff, 1995). Kesehatan fisik mempengaruhi kesejahteraan psikologis individu. Hal ini senada dengan faktor-faktor yang mempengaruhi kesejahteraan psikologis yang dikemukakan oleh Mirowsky dan Ross (1999) yang meliputi emosi dan kesehatan serta fungsi fisik, pekerjaan, pernikahan, anakanak, kondisi masa lalu seseorang terutama pola asuh keluarga, dan faktor kepercayaan.

Penelitian yang mendukung bahwa penyakit fisik mempengaruhi kesejahteraan psikologis seseorang antara lain Psychological Well-Being pada Penyandang Gagal Ginjal oleh Aini (2012). Penelitian ini menggambarkan bahwa kondisi fisik yang terganggu membuat mereka terbatas dalam melakukan aktivitas yang berhubungan dengan diri sendiri maupun aktivitas sosial. Hal ini terkait dengan aspek otonomi dan penguasaan lingkungan yang mereka lakukan. Penyandang gagal ginjal yang mengarahkan aktivitas pada tujuan hidupnya dan memiliki keyakinan untuk mencapainya maka mereka mampu mengembangkan diri secara personal. Hal ini menggambarkan bahwa penting bagi individu yang memiliki penyakit fisik untuk tetap memiliki tujuan hidup, aktivitas yang terarah dan keyakinan diri 
sehingga mampu menemukan potensi diri dan terus mengembangkannya untuk meraih kebahagiaan.

Gambaran di atas seiring dengan pendapat Papalia, Olds dan Feldman (2009) yang mengemukakan bahwa orang yang memiliki kesejahteraan psikologis yang baik adalah orang yang mampu merealisasikan potensi dirinya secara kontinu, mampu membentuk hubungan yang hangat dengan orang lain, memiliki kemandirian terhadap tekanan sosial, menerima diri apa adanya, memiliki arti dalam hidup, serta mampu mengontrol lingkungan eksternal. Kesejahteraan psikologis memiliki peranan dalam pencegahan dan penyembuhan suatu penyakit sehingga dapat meningkatkan harapan hidup penderita (Vazques dkk, 2009).

Beberapa penelitian yang telah dilakukan dan berhasil untuk meningkatkan kesejahteraan psikologis di antaranya yaitu Cognitive Behavior Therapy mampu meningkatkan kesejahteraan psikologis remaja gay (Wardani, 2014), Konseling "Kebermaknaan Hidup" mampu mempengaruhi kesejahteraan psikologis difabel yang dilakukan oleh Perwitasari (2012), Dewi (2012) melakukan penelitian yang membuktikan bahwa Pelatihan Manajemen Distres Berbasis Mindfulness (MDBM) dapat meningkatkan kesejah- teraan psikologis pada orang dengan HIV AIDS (ODHA). Group Positive Psychotherapy juga terbukti mampu meningkatkan kesejahteraan psikologis remaja yang dilakukan oleh Wardiyah (2013). Demikian pula Group Positive Psychotherapy yang dilakukan oleh Prabowo (2011) mampu meningkatkan Psychological Well-Being Mahasiswa di Universitas YARSI. Penelitian yang dilakukan oleh Hidayah (2014) membuktikan bahwa Group Positive Psychotherapy efektif untuk meningkatkan kesejahteraan psikologis pada orang dengan HIV/ AIDS (ODHA) di Boyolali.

Beberapa penelitian sebelumnya cukup banyak membuktikan group positive psychotherapy efektif dan berpengaruh signifikan untuk meningkatkan kesejahteraan psikologis namun belum pernah ada yang meneliti pengaruhnya terhadap penderita Diabetes Mellitus. Group positive psychotherapy adalah suatu model terapi dengan pendekatan kelompok yang menfokuskan upaya membangun hidup yang menyenangkan, hidup yang terikat kegiatan-kegiatan, dan hidup yang bermakna.

Menurut Parks-Sheiner (2009), Group positive psychotherapy merupakan intervensi untuk mencapai target hidup yang menyenangkan, keterlibatan dalam aktivitas, dan kebermaknaan hidup. 
Group positive psychotherapy terdiri dari beberapa teknik yaitu Tiga Hal Baik (Three Good Things), Pergunakan Kekuatanmu (Using Your Strenghts), Kunjungan Terimakasih (The Gratitude Visit), Biografi (Obituary), Respon Aktif/ Konstruktif (Active-Constructive Responding), Menikmati Kegiatan Sehari-hari (Savoring). Keenam teknik ini digunakan untuk mencapai tiga sasaran utama dalam group positive psychotherapy yaitu hidup yang menyenangkan, hidup terikat pada kesibukan, hidup yang bermakna (Seligman, 2006).

Oleh karena itu, peneliti ingin mengetahui peningkatan kesejahteraan psikologis pada penderita diabetes mellitus tipe 2 dengan menggunakan group positive psychotherapy. Hipotesis pada penelitian ini adalah group positive psychotherapy mampu meningkatkan kesejahteraan psikologis pada penderita diabetes mellitus tipe 2 dan kelompok yang mendapatkan intervensi group positive psychotherapy lebih tinggi tingkat kesejahteraan psikologis dibandingkan dengan kelompok yang tidak mendapatkan group positive psychotherapy.

\section{METODE PENELITIAN}

\section{Desain Penelitian}

Desain penelitian yang digunakan pada penelitian ini adalah kuasi eksperimen. Partisipan yang diambil adalah partisipan yang memenuhi salah satu atau dua kriteria sekaligus, yaitu masuk dalam kategori sedang, rendah, dan sangat rendah di dalam skala kesejahteraan psikologis. Pada penelitian ini metode eksperimen dilakukan dengan memberikan perlakuan berupa group positive psychotherapy untuk melihat peningkatan kesejahteraan psikologis pada penderita diabetes mellitus tipe 2 .

\section{Subjek Penelitian}

Populasi dalam penelitian ini adalah penderita diabetes mellitus tipe 2 yang berada di bawah wilayah kerja Puskesmas Ngemplak 1 dan Ngemplak 2, Sleman. Adapun kriteria subjek penelitian adalah memiliki diagnosa penyakit diabetes mellitus tipe 2, laki-laki atau perempuan berusia 47-64 tahun dengan alasan bahwa penyakit diabetes mellitus tipe 2 diderita antara usia pertengahan dan usia lanjut dengan serangan awal terjadi setelah usia 40 tahun, memiliki kemampuan baca dan tulis, tidak sedang mengikuti intervensi psikologis apapun, memiliki skor kesejahteraan psikologis dengan kategori sedang, rendah dan sangat rendah, serta bersedia mengikuti rangkaian penelitian dari prates hingga tindak lanjut. 


\section{Metode Pengumpulan Data}

Metode penelitian yang digunakan dalam melakukan pengumpulan data adalah dengan menggunakan observasi, wawancara, dan skala kesejahteraan psikologis. Skala yang digunakan merupakan skala yang dimodifikasi dari skala yang pernah ada dan dibuat oleh peneliti sebelumnya. Skala kesejahteraan psikologis disusun berdasarkan dimensi-dimensi kesejahteran psikologis yang dikemukakan oleh Ryff (1989), yaitu penerimaan diri, relasi positif dengan sesama, otonomi, penguasaan lingkungan, tujuan hidup, dan pertumbuhan pribadi.

Skala kesejahteraan psikologis ini terdiri atas 29 aitem favorable dan unfavorable. Setiap pernyataan dalam skala kesejahteraan psikologis ini meminta respon dari subjek dengan memilih salah satu alternatif jawaban yang telah disediakan. Skala ini disusun berdasarkan skala Likert yang terdiri atas 4 alternatif jawaban, yaitu sangat sesuai (SS), sesuai (S), tidak sesuai (TS) dan sangat tidak sesuai (STS). Hasil uji coba skala kesejahteraan psikologis menunjukkan bahwa dari 29 butir pernyataan, 22 butir dinyatakan sahih dan 7 butir dinyatakan gugur. Koefisien korelasi untuk skala yang sahih bergerak antara 0,319 hingga 0,682 . Hasil uji coba reliabilitas skala kesejahteraan psikologis menunjukkan bahwa koefisien korelasi sebesar 0,855.

\section{Prosedur Penelitian}

Adapun prosedur penelitian pada penelitian ini yaitu: Pertama, perijinan tempat untuk melakukan screening. Kedua, screening menggunakan skala penelitian kepada orang dengan Diabetes Mellitus Tipe 2. Hasil skala dengan kategori sedang dan rendah serta memenuhi kriteria dipilih menjadi subjek penelitian. Data ini juga digunakan sebagai prates. Ketiga, wawancara untuk menggali permasalahan dan pemberian Informed Consent kepada subjek penelitian. Keempat, penentuan kelompok kontrol dan kelompok eksperimen. Kelima, seleksi fasilitator dan ko-fasilitator, serta observer. Kelima, pelaksanaan intervensi Group Positive Psychotherapy pada kelompok eksperimen dan kelompok kontrol tidak mendapatkan intervensi.

\section{Teknik Analisis Data}

Penelitian ini menggunakan beberapa teknik analisis data. Teknik analisis data parametrik yang digunakan adalah one-way repeated measures anova, yaitu teknik analisis untuk melihat apakah ada perubahan (prates-pascates-tindak lanjut) pada kelompok eksperimen. Selain itu dilakukan juga uji independent sample $t$ - 
test untuk membandingkan kelompok eksperimen dan kelompok kontrol. Analisis dari variabel-variabel tersebut dilakukan dengan program komputer SPSS (Statistical Product and Service Solution) for windows.

\section{HASIL PENELITIAN}

Jumlah subjek penelitian pada kelompok eksperimen sebanyak 6 penderita diabetes mellitus tipe 2 , berjenis kelamin laki-laki dan perempuan. Subjek yang masuk ke dalam kelompok eksperimen merupakan anggota terapi yang dilakukan selama 3 kali pertemuan. Penelitian ini melakukan pengukuran sebanyak tiga kali, yaitu sebelum intervensi dilakukan (prates), setelah intervensi diberikan (pascates) dan 2 minggu setelah intervensi diberikan (tindak lanjut).

Hasil pengukuran pascates menunjukkan semua kelompok eksperimen mengalami peningkatan skor kesejahteraan psikologis setelah diberikan intervensi berupa group positive psychotherapy. Sedangkan pada kelompok kontrol terdapat 1 subjek yang mengalami peningkatan skor, 2 subjek yang mendapatkan skor tetap, dan 3 subjek yang mengalami penurunan skor.

Berdasarkan tabel analisis statistik, diketahui bahwa rata-rata skor pada prates kelompok eksperimen sebesar 49.33 dan kelompok kontrol 50.67. Hal ini berarti bahwa rata-rata skor pada kelompok kontrol lebih tinggi dari kelompok eksperimen. Sedangkan, setelah terapi (pascates) diketahui bahwa rata-rata skor kelompok eksperimen lebih tinggi dibanding kelompok control, yaitu 58.33 berbanding 50.33. Hal ini juga dialami pada tahap tindak lanjut, rata-rata skor kelompok eksperimen (57.00) lebih tinggi dibanding rata-rata skor kelompok kontrol (49.33).

Hasil uji normalitas dari skala kesejahteraan psikologis diperoleh nilai $\mathrm{K}-\mathrm{SZ}=0.631$ dan $\mathrm{p}=0.821$ sehingga penyebaran data skala kesejahteraan psikologis dapat dikatakan normal. Hasil uji homogenitas pada kelompok eksperimen dan kelompok kontrol pada penelitian ini memperoleh nilai levene statistic $=0.833$ dan nilai $p=0.383$ berarti nilai p $>0.05$ sehingga dapat dikatakan bahwa proporsi kedua kelompok adalah homogen.

Pada tabel analisis statistik, nilai Wilks' Lambda $=0.153, \quad p=0.00$ $(p<0.01)$ menunjukkan ada perubahan secara sangat signifikan pada skor kesejahteraan psikologis kelompok ekperimen dalam tiga kali pengukuran. Hal ini berarti bahwa terdapat perbedaan 
yang signifikan antara skor prates dengan pascates pada kelompok eksperimen, dan juga terdapat perbedaan yang signifikan antara skor prates dengan tindak lanjut pada kelompok eksperimen. Perbedaan antara skor prates-pascates-tindak lanjut yang dimaksud yaitu terjadi perubahan skor prates-pascates yang semakin meningkat berdasarkan nilai Mean kelompok eksperimen dari 49.33 menjadi 58.33. Pada tindak lanjut diperoleh Mean 57.00. Kedua Mean terlihat lebih tinggi jika dibandingkan dengan Mean prates. Nilai Partial Eta Square pada baris diperoleh nilai 0.847 , hal ini berarti bahwa sumbangan efektif sebesar 84,7.

Ada perbedaan kesejahteraan psikologis pada kelompok eksperimen dan kelompok kontrol setelah terapi diberikan, dengan nilai $p=0.000 \quad(p<0.01)$ pada saat prates-pascates dan $p=0.001$ $(p<0.01)$ pada saat prates-tindak lanjut.

\section{PEMBAHASAN}

Penelitian ini bertujuan untuk mengetahui peningkatan kesejahteraan psikologis pada penderita diabetes mellitus tipe 2 dengan menggunakan group positive psychotherapy. Berdasarkan hasil analisis data yang telah dilakukan diperoleh hasil bahwa group positive psychotherapy dapat meningkatkan kese- jahteraan psikologis pada penderita diabetes mellitus tipe 2 .

\section{Group positive psychotherapy} disusun untuk mengarahkan subjek penelitian pada kehidupan yang lebih positif melalui beberapa teknik latihan, seperti perkenalan positif dan mengenali kekuatan diri, mampu menemukan tiga hal baik setiap hari, kunjungan terimakasih melalui surat, savoring yang melatih subjek untuk lebih menikmati kehidupannya dimulai dari rutinitas yang ada, tanggapan aktif/konstruktif bertujuan untuk melatih subjek lebih positif dalam berkomunikasi, dan pembuatan biografi yang membantu subjek mengarahkan perilakunya sesuai tujuan hidup yang ingin dicapai.

Ketika subjek mendapat diagnosis diabetes mellitus yang pengelolaan penyakitnya dengan minum obat seumur hidup, diet makanan dan sebagainya cenderung membuat subjek merasa tidak lagi memiliki potensi dalam diri untuk melakukan berbagai aktivitas positif. Pada awal pertemuan, subjek dihadapkan pada kegiatan perkenalan positif dan mengenali kekuatan diri. Subjek yang mengalami kesulitan untuk melakukan perkenalan positif dibantu oleh fasilitator dan anggota kelompok untuk menemukan hal positif yang ada pada masingmasing subjek. Hal ini didasarkan pada 
asumsi bahwa perilaku patologis disebabkan oleh kurangnya kesadaran tentang potensi positif dalam diri individu (Magyar-Moe, 2009). Pengenalan potensi positif ini seiring dengan pernyataan yang tercantum dalam Al-Quran yaitu manusia diciptakan oleh Allah SWT dengan struktur yang paling baik di antara makhluk Allah SWT yang lain. Kesempurnaan unsur manusia disebutkan dalam firman Allah SWT yang artinya :

"Sungguh, Kami telah menciptakan manusia dalam bentuk yang sebaikbaiknya." (Q.S. At-Tin: 4).

Pada sesi kekuatanku, subjek penelitian dilatih untuk tetap fokus pada hal positif yang ada di dalam diri sehingga tetap menumbuhkan semangat dan optimisme. Ryan dan Deci (2001) mengungkapkan bahwa optimisme memberi kontribusi terhadap kesejahteraan atau kebahagiaan individu.

"Allah tidak akan membebani seseorang (hamba-Nya) melainkan sesuai dengan kemampuannya (QS. Al-Baqarah: 286).

Menurut perspektif Islam, mengarahkan subjek penelitian pada kehidupan yang lebih positif memiliki kesamaan dengan berprasangka baik (khusnudzon). Salah satu akhlak mahmudah (terpuji) kepada Allah SWT adalah khusnudzon (berbaik sangka atau berpikir positif) kepada-Allah adalah Tuhan Yang Maha Pengasih dan Penyayang. Ketika seseorang meyakini bahwa Allah mengasihi seluruh makhluk-Nya dan menganugerahkan rezeki kepada semua makhlukNya. Tidak peduli makhluk-Nya taat atau durhaka, muslim atau kafir. Bahkan, binatang dan tumbuh-tumbuhan pun dijamin rezekinya oleh Allah SWT maka akan menimbulkan rasa optimis menjalani hidup.

"Dan tidak ada suatu binatang melata pun di bumi melainkan Allahlah yang memberi rezkinya." (Q.S. Hud: 6).

Mengenali potensi positif dan melakukan aktivitas-aktivitas positif menghadirkan kesejahteraan pada dirinya (Salami, 2010). Hal ini seiring dengan pernyataan yang dikemukakan Frederickson dan Joiner (2002) bahwa seseorang yang memiliki sifat positif dan optimis berkorelasi positif dengan kesejahteraan individu. Selain itu, sesi tiga hal baik, kunjungan terimakasih dan savoring mengajarkan subjek penelitian untuk senantiasa lebih bersyukur terhadap kebaikan yang telah diterima setiap hari.

"Dan jika kamu menghitung-hitung 
nikmat Allah, niscaya kamu tak dapat menentukan jumlahnya. Sesungguhnya Allah benar-benar Maha Pengampun lagi Maha Penyayang." (QS. An-Nahl: 18).

"Sesungguhnya jika kamu bersyukur, pasti Kami akan menambah (nikmat) kepadamu, dan jika kamu kufur (mengingkari nikmat-Ku), maka sesungguhnya adzab-Ku sangat pedih" (QS. Ibrahim: 7).

Demikian pula dengan kegiatan tanggapan aktif/konstruktif yang melatih subjek penelitian tetap menjaga hubungan interpersonal dengan baik. Ketika individu mampu menjalin hubungan interpersonal dengan lingkungan secara aktif maka menurut Ryff (1995) individu tersebut memiliki gambaran kesejahteraan psikologis pada aspek hubungan positif dengan oranglain dan penguasaan terhadap lingkungan. Hal ini juga merupakan wujud syukur kepada Allah.

Manusia yang bersyukur kepada manusia/makhluk lain adalah dia yang memuji kebaikan serta membalasnya dengan sesuatu yang lebih baik atau lebih banyak dari apayang telah dilakukan oleh yang disyukurinya itu. Syukur yang demikian dapat juga merupakan bagian dari syukur kepada Allah. Sebab, berdasarkan hadis Nabi SAW yang artinya:
"Siapa yang tidak mensyukuri manusia maka dia tidak mensyukuri Allah (HR. Abu Daud dan AtTurmuzi).

Evaluasi dari keseluruhan rangkaian terapi menunjukkan bahwa semua subjek merasa senang karena mampu bertukar cerita, berkeluh kesah dan belajar dari anggota kelompok yang lain. Subjek diminta untuk menceritakan situasi emosional dimana kondisi tersebut membantu seseorang untuk meningkatkan rasa syukur yang berpengaruh pada kondisi fisik dan psikologisnya. Menulis dan atau membicarakan topik emosional ditemukan mempengaruhi fungsi imun termasuk perkembangan sel t-helper, dan antibody (Pennebaker \& Chung, 2007).

Beberapa penelitan mendukung bahwa interaksi dengan orang terdekat yang dilakukan secara aktif dan konstruktif dapat meningkatkan kebahagiaan, kepuasan, kepercayaan, keakraban dan mengurangi konflik (Magyar-Moe, 2009). Group positive psychotherapy telah terbukti mampu meningkatkan kesejahteraan psikologis penderita diabetes mellitus tipe 2. Hal ini erat kaitannya dengan optimisme subjek dalam menghadapi penyakitnya. Seiring dengan pendapat yang dikemukakan oleh Vazques dkk (2009) bahwa kesejahteraan psikologis memiliki peranan dalam 
pencegahan dan penyembuhan suatu penyakit sehingga dapat meningkatkan harapan hidup penderita.

Penelitian ini didukung oleh penugasan-penugasan yang diberikan pada akhir setiap pertemuan, yang kemudian didiskusikan dalam kelompok. Tugas rumah memberikan kesempatan kepada subjek untuk dapat melatih dirinya menerapkan teknik-teknik yang dipelajari di dalam kelompok kepada kehidupan sehari-hari. Kemudian diskusi tugas rumah dapat memberikan umpan balik dan penguatan terhadap aktivitas positif yang telah dilakukan dengan baik oleh setiap subjek.

Intervensi dalam penelitian ini dipengaruhi juga oleh rancangan intervensi dalam bentuk kelompok. Pendekatan kelompok dianggap memiliki manfaat terapeutik terhadap kelompok, yaitu sebagai faktor dukungan, faktor keterbukaan diri dan katarsis, faktor belajar kebijaksanaan atau kearifan dari anggota kelompok lainnya, serta faktor-faktor psikologis yang berkaitan dengan bagaimana menjalin hubungan dengan orang lain dan bagaimana memahami diri sendiri (Brabenden, Fallon, \& Smolar, 2004). Seiring dengan pendapat yang dikemukakan oleh Jacobs dkk (2002) bahwa keuntungan terapi yang menggunakan pendekatan kelompok yaitu lebih efisien karena menawarkan banyak sudut pandang, perasaan senasib, pengalaman terlibat dengan orang lain, kesempatan belajar pengalaman-pengalaman orang lain berdasarkan hasil mendengar dan mengobservasi, kesempatan mendapat umpan balik sehingga akan memegang teguh komitmennya selama terapi.

Berdasarkan hasil kuantitatif setiap subjek, ke enam subjek mengalami peningkatan kesejahteraan psikologis setelah mengikuti group positive psychotherapy meskipun pada tahap tindak lanjut terjadi peningkatan dan penurunan yang beragam antar subjek. Hasil penelitian ini mendukung penelitian terdahulu yang telah dilakukan oleh Hidayah (2014) yang menunjukkan bahwa ada pengaruh group positive psychotherapy terhadap peningkatan kesejahteraan psikologis pada orang dengan HIV/AIDS. Hal ini juga sesuai dengan penelitian Wardiyah pada tahun 2013 membuktikan bahwa kesejahteraan psikologis mampi ditingkatkan dengan group positive psychotherapy. Penelitian yang dilakukan oleh Prabowo (2011) membuktikan hal yang sama bahwa group positive psychotherapy mampu meningkatkan psychological well-being pada mahasiswa.

Selain itu, perlu dilakukan sejum- 
lah evaluasi. Modul intervensi tidak melalui uji coba sebelumnya. Fasilitator cenderung sering menambahkan penjelasan instruksi kepada subjek penelitian agar subjek mampu melaksanakan instruksi dengan baik. Modul diterapkan secara runtut sesuai dengan rancangan pelaksanaan meskipun terdapat modifikasi seperti diberikannyaa ice breaking ketika beberapa subjek terlihat bosan atau kurang konsentrasi ketika proses terapi yang sebelumnya tidak dituliskan dalam modul terapi.

Evaluasi perubahan kesejahteraan psikologis subjek penelitian ini belum melalui wawancara dengan caregiver. Peneliti melakukan evaluasi perubahan kesejahteraan subjek melalui wawancara langsung dengan subjek, baik sebelum maupun sesudah intervensi. Hasil evaluasi cenderung berpusat pada pengakuan subjek penelitian saja.

Penelitian ini menggunakan data dari Puskesmas yang tidak memiliki komunitas khusus penderita diabetes mellitus tipe 2 dan alamat lengkap sehingga pengambilan data harus dilakukan kunjungan ke rumah masingmasing subjek.

\section{SIMPULAN \& SARAN}

\section{Simpulan}

Berdasarkan hasil penelitian yang telah dilakukan maka dapat disimpulkan bahwa group positive psychotherapy dapat meningkatkan kesejahteraan psikologis pada penderita diabetes mellitus tipe 2. Kelompok yang mendapatkan intervensi group positive psychotherapy lebih tinggi tingkat kesejahteraan psikologis dibandingkan dengan kelompok yang tidak mendapatkan group positive psychotherapy.

\section{Saran}

Untuk penelitian selanjutnya: (1) Penelitian ini menggunakan data dari Puskesmas yang tidak memiliki komunitas khusus penderita diabetes mellitus tipe 2 dan alamat lengkap. Jika peneliti selanjutnya menemukan keterbatasan data yang sama, peneliti menyarankan untuk menelusuri melalui kepala dusun atau dukuh agar dapat mempermudah melakukan kunjungan rumah; (2) Alat ukur ini bisa digunakan kembali oleh penelitian selanjutnya dengan kriteria subjek yang sama; (3) Peneliti menyarankan untuk melakukan uji coba modul sehingga penggunaan lembar kerja, waktu dan bahasa instruksi dapat lebih sesuai dengan karakteristik subjek; (4) 
Peneliti selanjutnya diharapkan dapat melakukan penelitian sejenis dengan memperhatikan berbagai variabel lain yang mempengaruhi kesejahteraan psikologis penderita diabetes mellitus tipe 2 , serta dapat mengembangkan group positive psychotherapy sebagai alternatif intervensi untuk kasus psikologis penyakit kronis lainnya.

Untuk subjek penelitian: (1) Subjek penelitian diharapkan dapat menerapkan pengetahuan dan cara-cara meningkatkan kesejahteraan psikologis yang didapatkan dari group positive psychotherapy dalam kehidupan sehari-hari; (2) Subjek penelitian bisa meningkatkan kemampuan bersosialisasi dengan lingkungan sekitar sehingga tidak banyak berdiam diri di rumah, tidak jenuh dan tidak terfokus pada keterbatasan diri akan penyakit.

\section{DAFTAR PUSTAKA}

Abbott, R.A., Ploubidis, G.B., Huppert, F.A., Kuh, D., Wadsworth, M.E.J. \& Croudace, T.J. (2006). Psychometric Evaluation and Predictive Validity of Ryff's Psychological Well-Being Items in a UK Birth Cohort Sample of Women. Health and Quality of Life Outcomes. BioMed Central Ltd. 4: 76.

Aini, S. N., \& Asiyah, S.N. (2013). Psychological Well Being Penyan- dang Gagal Ginjal. Jurnal Penelitian Psikologi, 4,(1), 35-45

Anantasari, M. L. (2004). Kesejahteraan Psikologis Orang Tua dan Perlakuan Salah terhadap Anak. Tesis. Tidak diterbitkan. Yogyakarta: Fakultas Psikologi Universitas Gadjah Mada

Askandar, T. (1999). Diabetes Mellitus Klasifikasi Diagnosis dan Terapi. Jakarta: PT Gramedia Pustaka Utama

Baron, J. (1988). Thinking and Deciding. New York: Cambridge University Press

Bartram, D. \& Boniwel, L. (2007). The Science of Happiness: Achieving Sustained Psychological WellBeing. Positive Psychology in Practice, 29, 478-482

Bradburn, N. M. 1969. The Structure of Psycholgical Well Being. Chicago: Aldine

Buckman,Dr. Robert \& McLaughlin, Chris. (1999). Apa yang seharusnya Anda ketahui tentang hidup dengan Diabetes. London: Marshall Publishing Ltd

Compton, W.C. (2005). Introduction to Positive Psychology. Singapore: Thomson Wadsworth 
DepKes. (2013). Riset Kesehatan Dasar Indonesia Tahun 2013. Yogyakarta: Departemen Kesehatan

Dewi, R.P. (2012). Pengaruh Pelatihan Manajemen Distres Berbasis Mindfulness (MDBM) terhadap Peningkatan Kesejahteraan Psikologis pada Orang dengan HIV/AIDS. Tesis. Tidak diterbitkan. Yogyakarta: Fakultas Psikologi Universitas Gadjah Mada

Eckhalm E.P. (1999). Masalah Kesehatan. Jakarta: PT. Gramedia Pustaka Utama

Feldman, R. S. (1997). Social Psychology. New Jersey: Prentice Hall

Frederickson, B.L. \& Joiner, T. (2002). Positive Emotions Triger Upwardn Spirals Toward Emotion Well Being. Psychological Science, 13, 172-175

Hidayah, N. (2014). Efektivitas Group Positive Psychotherapy untuk Meningkatkan Kesejahteraan Psikologis pada Orang dengan HIV/AIDS (ODHA). Tesis. Tidak diterbitkan. Surakarta: Program Pendidikan Magister Psikologi Profesi Universitas Muhammadiyah Surakarta

Ingersoll-Dayton, B.S. (2004). Measuring Psychological Well-Being: Insight from Thai Elders. Journal of Gerontologist, 44(5), 596-604

Jacobs, E.E., Robert, L.M., \& Riley, L.H. (2002). Group Counseling: Strategies and Skills. Canada: The Wadsworth Group, a division of Thompson Learning,Inc.

Karlsen, B, Bru, E \& Hanestad, R. (2002). Self-Reported PWB and DiseaseRelated Strains among Adults with Diabetes. Psychological and Health. 17 (4), 459-473

Kartikasari, N.D. (2014). Hubungan antara Religiusitas dengan Kesejahteraan Psikologis pada Penderita Diabetes Mellitus Tipe 2. Skripsi. Tidak diterbitkan. Surakarta: Fakultas Psikologi Universitas Muhammadiyah

Keyes, C.R. (2006). A Look at Children's Adjustment to Early Childhood Programs. Early Childhood Research \& Practice, 8(2), 22-36

Kusumadewi, M.D. (2011). Peran Stressor Harian, Optimisme dan Regulasi Diri terhadap Kualitas Hidup Individu dengan Diabetes Melitus Tipe 2. Psikoislamika Jurnal Psikologi Islam, (8), 1, 43-62

Latifah,N. (2014). Kesejahteraan Psikologis Pada Wanita Dewasa Muda Yang Belum Menikah. Skripsi. 
Tidak diterbitkan. Yogyakarta: Program Studi Bimbingan dan Konseling Universitas Negeri Yogyakarta

Lopez S. J., \& Snyder C. R. (2003). The Measurement and Utility of Adult Subjective Well-Being. Washington DC: American Psychological Association

Lumantobing. (2008). Psikologi Kesehatan. Yogyakarta: Mitra Cendikia

Magyar-Moe, J. L. (2009). Therapist's Guide to Positive Psychological Interventions. ( $1^{\text {st }}$ Edition $)$. Academic Press, pp. 79-133y 151175

Mambangsari, C.W. (2012). Pengaruh Program Edukasi Perawatan Kaki Berbasis Keluarga terhadap Perawatan Kaki pada Pasien Diabetes Mellitus tipe 2. Tesis. Tidak diterbitkan. Bandung: Program Pendidikan Magister Program Studi Keperawatan

Martalena, B. P. (1999). Pengaturan Makanan Diabetes. Pusat Diabetes Yogyakarta

Maulana, M. (2008). Mengenal Diabetes Melitus. Jogjakarta: Katahati

Miller, S.M. \& Schnoll, R.A. (2000) When Seeing Is Feeling: A Cognitive-
Emotional Approach to Coping with Health Status dalam Handbook of Emotions Second Edition. New York: The Guilford Press.

Mirowsky \& Ross. (1999). Well-Being Across the Life Course. Cambridge: Cambridge University Press

Neugarten, B.L., Havighurst, R., \& Tobin, S. (1961). The Measurement of Life Satisfaction. Journal of Gerontology. 16, 134-143

Notosoedirdjo dan Latipun. 2005. Kesehatan Mental : Konsep dan Penerapan. Malang : UMM Press.

Nuryati, S. (2009). Gaya Hidup dan Status Gizi serta Hubungannya dengan Hipertensi dan Diabetes Melitus Pada Pria dan Wanita Dewasa di DKI Jakarta. Tesis. Tidak diterbitkan. Bandung: Pasca Sarjana Institut Pertanian Bogor.

Nussbaum, M.C., \& Sen, A.K. (1993). The Quality of Life. Oxford: Clarendon Press

Papalia, Olds, Feldman. (2009). Human Development. Jakarta: Salemba

Park-Shiner, A.C. (2009). Positive Psychotherapy: Building a Model of Empirically Supported Self-Help. Dissertation. Pennsylvania: Facul- 
ties Psychology of the University Pennsylvania

Pebriartati, S. (2011). Pelatihan Pemaafan untuk Meningkatkan Kesejahteraan Psikologis Wanita Bercerai. Tesis. Tidak diterbitkan. Yogyakarta: Fakultas Psikologi Universitas Gadjah Mada

Pennebaker, J.W., \& Chung, C.K. (2007). Expressive Writing: connections to physical and mental health. The University of Texas at Austin

Perkeni. (2002). Konsesus Pengelolaan Diabetes Mellitus Tipe 2 Di Indonesia 2002. PB PERKENI.

Perwitasari, F. (2012). Pengaruh Konseling "Kebermaknaan Hidup" terhadap Kesejahteraan Psikologis Difabel. Tesis. Tidak diterbitkan. Yogyakarta: Fakultas Psikologi Universitas Gadjah Mada

Peseschkian, N. And K. Triit. (1998). Positive Psychotherapy: Effectiveness Study and Quality Assurance. The european journal of psychotherapy, counseling \& health, 1, 42-53

Pouwer, F., Snoek, F. J., Ploeg, H. M., Ader, H. J. \& Heine, R. J. (2001). Monitoring of Psychological Wellbeing in Outpatients with Diabetes. Diabetes Care, 24 (11) 1929-1935
Prabowo, A. \& Yuniardi, M.S. (2011). Pengaruh Group Positive Psychotherapy terhadap Psychological Well Being Mahasiswa. Dipresentasikan di Konferensi Nasional, Universitas YARSI, 5 November 2011

Prawitasari, J.E. (2011). Psikologi Klinis Pengantar Terapan Mikro dan Makro. Jakarta: Penerbit Erlangga

Purnomosidi, I. (2014). Hubungan Intensitas Olahraga terhadap Psychological Well-Being. Skripsi. Tidak diterbitkan. Yogyakarta: Program Studi Psikologi Universitas Islam Indonesia

Ryan, R. M \& Deci, E.L. 2001. On Happines and Human Potentials: A Review of Research on Hedonic and Eudaimonic Well-Being. Annual Reviews, 52, 141-166

Ryff, C.D. and Keyes, L.M. (1995). The Structure of Psychological WellBeing revisited. Journal of Personality and Social Psychogy, 69 (4), 719-727

. (1995). Psychological wellbeing in adult life. Current Directions in Psychological Science, 57(6), 99-104

(1989). Happiness Is Everything, or Is It? Explorations on 
the Meaning of Psychological Well Being. Journal of Personality and Social Psychology, 57 (6), 10691081

Salami, S. O. (2010). Emotional Intelligence, Self-Efficacy, Psychological Well-Being And Students' Attitudes: Implivations For Quality Education. European Journal of Educational Studie, 2(3), 247-257

Sam, A.D.P. (2007). Epidemiologi DM dan isu mutakhirnya. http://www. newparadigmforpublichealth.htm. Diakses 2 Mei 2015

Sarafino, E.P. 1997. Health Psycholoogy; Biopsychological Interactions. Third Edition. USA: John Wiley \& Sons, Inc.

Seligman, M.E.P., Rashid, T., \& Parks, A.C. (2006). Positive Psychotherapy. Journal of American Psychologist, 61, 774-788

Shadish, W. R., Cook, T. D., \& Campbell, D. T. (2002). Experimental and Quasi-Experimental Designs for Generalized Causa Inference. Boston: Houghton Mifflin Company

Singh, B., \& Udainiya R. (2009). SelfEfficacy and Well-Being of Adolescents. Journal of the Indian
Academy of Applied Psychology, 35(2), 227-232

Skovlund, S.E., \& Peyrot, M. (2005). The Diabetes Attitudes, Wishes, and Needs (DAWN) program: A new approach to improving outcomes of diabetes care. Diabetes Spectrum. 18(3), 136-142

Taylor, S. E. 2006. Health Psychology. New York: McGraw-Hill Companies, Inc.

Temane, Q.M \& Wissing, M. P. 2006. The Role of Subjective Perception of Health in The Dynamics of Context and PWB. South African Journal of Psychology. 36 (3), 564581

Tjokroprawiro, A. (2006). Hidup Sehat dan Bahagia Bersama Diabetes Militus. Edisi kesembilan. Jakarta : Gramedia Pustaka

Vazquez, dkk. (2009). Psychological Well-Being and Health. Contributions of Positive Psychology. Annuary of Clinical and Health Psychology, (5) 15-27

Wardani, A. (2014). Cognitive Behavior Therapy untuk Meningkatkan Kesejahteraan Psikologis Remaja Gay. Tesis. Tidak diterbitkan. Medan: Fakultas Psikologi Universitas Sumatera Utara 
Wardiyah, Malahatul. (2013). Group Positive Psychotherapy untuk Meningkatkan Kesejahteraan Psikologis Remaja. Jurnal Sains dan Praktik Psikologi, 1 (2), 139-152

Winasis, E. B. (2009). Hubungan antara Konsep Diri dengan Depresi pada Penderita Diabetes Mellitus di Puskesmas Pracimantoro I Wonogiri. Skripsi. Tidak diterbitkan. Surakarta: Universitas Muhammadiyah Surakarta

World Health Organization. Definition and diagnosis of diabetes mellitus and intermediate hyperglycemia. Amerika Serikat; 2006. Tersedia pada: URL: http://www.idf.org/
webdata/docs/WHO_IDF_definitio n_diagnosis_of_diabetes.pdf [diakses 7 April 2015].

Yalom, I.D. \& Leszcz, Molyn. (2005). The theory and practice of group psychotherapy. New York : Basic Books

Yulishati. (2014). Efektifitas Edukasi Diabetes Terpadu Untuk Meningkatkan Efikasi Diri Pasien Diabetes Mellitus Tipe 2. Tesis. Tidak diterbitkan. Sumatera Utara: Fakultas Keperawatan Sumatera Utara. http://repository.usu.ac.id/ handle/ 123456789/42401 Diakses tanggal 8 April 2015 